\title{
Acidisoma tundrae gen. nov., sp. nov. and Acidisoma sibiricum sp. nov., two acidophilic, psychrotolerant members of the Alphaproteobacteria from acidic northern wetlands
}

Correspondence Svetlana N. Dedysh dedysh@mail.ru

\author{
Svetlana E. Belova, ${ }^{1}$ Timofei A. Pankratov, ${ }^{1}$ Ekaterina N. Detkova, ${ }^{1}$ \\ Elena N. Kaparullina ${ }^{2}$ and Svetlana N. Dedysh ${ }^{1}$
}

\author{
${ }^{1}$ S.N. Winogradsky Institute of Microbiology, Russian Academy of Sciences, Prospect 60-letya \\ Octyabrya 7/2, Moscow 117312, Russia \\ ${ }^{2}$ G.K. Skryabin Institute of Biochemistry and Physiology of Microorganisms, Russian Academy of \\ Sciences, Pushchino, Moscow region 142292, Russia
}

Representatives of the class Alphaproteobacteria are common inhabitants of acidic aquatic and terrestrial environments, such as acidic hot springs, mine waters, acidic soils and Sphagnum-dominated wetlands (Harrison, 1981; Kishimoto et al., 1995; Hiraishi et al., 1998, 2000; Nogales et al., 2001; Dedysh et al., 2006; García-Moyano

The GenBank/EMBL/DDBJ accession numbers for the $16 \mathrm{~S}$ rRNA gene sequences of strains $\mathrm{WM}^{\top}{ }^{\top}, \mathrm{TPB}^{\mathrm{T}} \mathrm{6}^{\top}$ and TPB621 are AM947652, AM947653 and AM947654, respectively.

Phase-contrast micrographs of cells of strains $\mathrm{WM}^{\top}{ }^{\top}$ and $\mathrm{TPB} 606^{\top}$, a figure showing the influence of the $\mathrm{pH}$ of the medium on growth of strain $\mathrm{WM}^{\top}$, and two-dimensional thin-layer chromatographs of polar lipid extracts obtained from strains $\mathrm{TPB}^{\mathrm{N}} 06^{\top}$ and $\mathrm{WM} 1^{\top}$ are available as supplementary material with the online version of this paper. et al., 2007). In acidic peat bogs, the Alphaproteobacteria were detected by fluorescence in situ hybridization to be the most abundant bacterial population (Dedysh et al., 2006). Few of the alphaproteobacterial 16S rRNA gene sequences retrieved from this acidic habitat were affiliated with the phylogenetic lineage defined by the genera Acidisphaera and Acidiphilium. Here, the isolation of three representative members of this phylogenetic lineage from acidic Sphagnum peat is reported. The characteristics of these novel isolates are described, on the basis of which they are considered to represent two novel species of a new genus within the Alphaproteobacteria.

Strain $\mathrm{WM}^{\mathrm{T}}$ was isolated from acidic Sphagnum peat ( $\mathrm{pH} 4.5)$ collected in July 2003 from the upper $(0-10 \mathrm{~cm})$ 
oxic layer of the unnamed oligotrophic tundra wetland located in the Vorkuta region of northern Russia $\left(67^{\circ} \mathrm{N} 63^{\circ}\right.$ E). Isolation was by spread-plating serially diluted peat suspension onto the surface of medium $\mathrm{MB}$ comprising (per litre distilled water): $0.5 \mathrm{~g}$ glucose, $0.1 \mathrm{~g} \mathrm{KH}_{2} \mathrm{PO}_{4}, 0.25 \mathrm{~g}$ $\mathrm{KNO}_{3}, 0.1 \mathrm{~g} \mathrm{MgSO}_{4} .7 \mathrm{H}_{2} \mathrm{O}, 0.02 \mathrm{~g} \mathrm{CaCl}_{2} \cdot 2 \mathrm{H}_{2} \mathrm{O}, 0.1$ g yeast extract and $18 \mathrm{~g}$ agar-agar (Difco). After sterilization, the $\mathrm{pH}$ of the medium was adjusted to 3.5 with $0.1 \mathrm{M} \mathrm{H}_{3} \mathrm{PO}_{4}$. Strains TPB606 ${ }^{\mathrm{T}}$ and TPB621 were isolated from acidic peat soil ( $\mathrm{pH} 4.2$ ) sampled in August 2006 at a depth of 10-20 cm of the Sphagnum peat bog Bakchar, Tomsk region, western Siberia ( $56^{\circ} 51^{\prime} \mathrm{N} 82^{\circ} 50^{\prime} \mathrm{E}$ ). The medium used comprised (per litre distilled water): $0.5 \mathrm{~g}$ laminarin (for isolation of strain $\mathrm{TPB}^{2} 6^{\mathrm{T}}$ ) or xylan (for isolation of strain TPB621), $0.04 \mathrm{~g} \mathrm{MgSO}_{4} .7 \mathrm{H}_{2} \mathrm{O}, 0.02 \mathrm{~g} \mathrm{CaCl}_{2} .2 \mathrm{H}_{2} \mathrm{O}, 0.05 \mathrm{~g}$ yeast extract, $0.03 \mathrm{~g}$ galacturonic acid sodium salt, 0.03 g glucuronic acid and $1 \mathrm{ml}$ of humic acid dialysate. The $\mathrm{pH}$ of the medium was adjusted to 4.2. White or cream-coloured, raised, smooth, slimy colonies developed on plates inoculated with the terminal dilutions of these peat suspensions. Colonies consisted of coccobacilli that possessed large polysaccharide capsules. Partial sequencing of the $16 \mathrm{~S}$ rRNA genes from these isolates showed that they were affiliated with the Alphaproteobacteria but were related only distantly (91-94\% sequence similarity) to members of the genera Acidisphaera, Rhodopila, Acidiphilium and Acidocella. Thus, the goal of the present study was to describe the characteristics of the newly isolated strains and to determine their taxonomic position.

The isolates were maintained on agar medium containing (per litre distilled water): $0.5 \mathrm{~g}$ sodium gluconate, $0.1 \mathrm{~g}$ $\mathrm{KH}_{2} \mathrm{PO}_{4}, 0.25 \mathrm{~g}\left(\mathrm{NH}_{4}\right)_{2} \mathrm{SO}_{4}, 0.2 \mathrm{~g} \mathrm{MgSO}$. $7 \mathrm{H}_{2} \mathrm{O}, 0.05 \mathrm{~g}$ $\mathrm{CaCl}_{2} \cdot 2 \mathrm{H}_{2} \mathrm{O}, 0.2 \mathrm{~g} \mathrm{NaCl}, 0.1$ g yeast extract and $18 \mathrm{~g}$ agaragar (Difco). Morphological observations and cell size measurements were made with a Zeiss Axioplan 2 microscope and Axiovision 4.2 software (Zeiss). Preparation of ultrathin sections for electron microscopy was performed as described by Kulichevskaya et al. (2006). Absorption spectra of acetone/methanol $(7: 2, \mathrm{v} / \mathrm{v})$ extracts of cells of the new isolates were determined between 250 and $1000 \mathrm{~nm}$ with an SPh-56 spectrophotometer (LomoSpectrum). Physiological tests were carried out in liquid medium MB containing sodium gluconate instead of glucose. Growth of the novel strains was monitored by nephelometry at $410 \mathrm{~nm}$ by using a Specol spectrophotometer (Carl Zeiss) for 14 days under various conditions, including temperatures of $2-37{ }^{\circ} \mathrm{C}, \mathrm{pH} 2.8-8.0$ and $\mathrm{NaCl}$ concentrations of $0-3.0 \%(\mathrm{w} / \mathrm{v})$. Variations in $\mathrm{pH}$ were achieved by mixing $0.1 \mathrm{M}$ solutions of $\mathrm{H}_{3} \mathrm{PO}_{4}, \mathrm{KH}_{2} \mathrm{PO}_{4}$, $\mathrm{K}_{2} \mathrm{HPO}_{4}$ and $\mathrm{K}_{3} \mathrm{PO}_{4}$ to create media with the same ionic strength. The range of potential growth substrates for the novel strains was examined by replacing glucose in medium $\mathrm{MB}$ with single carbon sources. Growth in the presence of nitrogen sources was tested by using liquid medium $\mathrm{MB}$, in which $\mathrm{KNO}_{3}$ was replaced with one of the following compounds at a concentration of $0.05 \%(\mathrm{w} / \mathrm{v})$ : $\left(\mathrm{NH}_{4}\right)_{2} \mathrm{SO}_{4}, \mathrm{NH}_{4}$ formate, $\mathrm{NaNO}_{2}, \mathrm{NH}_{2} \mathrm{OH}-\mathrm{HCl}$, urea or one of the amino acids listed in Table 1. Except for growth temperature experiments, batch cultures were incubated on a rotary shaker at 180 r.p.m. and at $24{ }^{\circ} \mathrm{C}$. The capacity to degrade different biopolymers was examined by measuring the rate of $\mathrm{CO}_{2}$ production in tightly closed $120-\mathrm{ml}$ serum bottles containing $20 \mathrm{ml}$ liquid $\mathrm{MB}$ medium with $0.05 \%$ $(\mathrm{w} / \mathrm{v})$ of the corresponding polymer substrate for 1 month at $20{ }^{\circ} \mathrm{C}$. Control incubations were run in parallel under the same conditions but without substrate. Oxidative and fermentative utilization of carbohydrates was determined as described for the Hugh-Leifson test (Gerhardt et al.,

Table 1. Differential characteristics of strains $\mathrm{WM} 1^{\top}$ (Acidisoma tundrae gen. nov., sp. nov.) and TPB606 $^{\top}$ and TPB621 (Acidisoma sibiricum gen. nov., sp. nov.)

The two strains utilized arabinose, fructose, galactose, xylose, glucose, glycerol, mannitol, sorbitol, myo-inositol, sorbose, dulcitol, gluconate, pyruvate, galacturonate, yeast extract, Casamino acids, peptone and asparagine. They were capable of hydrolysing starch, xylan, heparin and aesculin. Neither of the strains utilized maltose, raffinose, methanol, butanol, propanol, fumarate, oxalate, succinate, acetate, citrate, formate, propionate, capronate, benzoate, glucuronic acid, alanine, aspartate or leucine. Neither strain was capable of hydrolysing alginate, chondroitin sulfate, carboxymethylcellulose, pullulan, casein or Tween 80 , or of gelatin liquefaction. The two strains utilized ammonia, urea, nitrate, yeast extract, glutamine, proline, histidine $\mathrm{HCl}$ and methionine as nitrogen sources. Neither strain utilized nitrite, $\mathrm{NH}_{2} \mathrm{OH}-\mathrm{HCl}$, lysine, arginine, glycine, serine or $\mathrm{NH}_{4}$ formate as nitrogen sources. Neither strain was capable of dissimilatory nitrate reduction. +, Positive; - , negative, $v$, variable.

\begin{tabular}{|c|c|c|}
\hline Characteristic & Strain $\mathrm{WM} 1^{\mathrm{T}}$ & $\begin{array}{c}\text { Strains TPB606 } \\
\text { and TPB621 }\end{array}$ \\
\hline Cell size $(\mu \mathrm{m})$ & $0.8-1.5 \times 1.9-4.1$ & $0.7-1.2 \times 1.4-3.1$ \\
\hline Colony colour & White, ivory & $\begin{array}{c}\text { White, cream, } \\
\text { pinkish }\end{array}$ \\
\hline Temperature range $\left({ }^{\circ} \mathrm{C}\right)$ & $2-30$ & $2-30$ \\
\hline Temperature optimum $\left({ }^{\circ} \mathrm{C}\right)$ & $15-22$ & $20-25$ \\
\hline $\mathrm{pH}$ growth range & $3.0-7.5$ & $3.7-7.6$ \\
\hline pH optimum & $4.5-5.7$ & $5.0-6.5$ \\
\hline $\mathrm{NaCl}$ tolerance $(\%, \mathrm{w} / \mathrm{v})$ & $<1.5$ & $<2.5$ \\
\hline \multicolumn{3}{|l|}{ Carbon source utilization } \\
\hline Lactose & - & $\mathrm{v}$ \\
\hline Mannose & + & $\mathrm{v}$ \\
\hline Sucrose & - & $\mathrm{v}$ \\
\hline Trehalose & + & $\mathrm{v}$ \\
\hline Cellobiose & - & $\mathrm{v}$ \\
\hline Ethanol & + & - \\
\hline Lactate, malate, butyrate & + & - \\
\hline Pectin & + & - \\
\hline Fucoidan & + & $\mathrm{v}$ \\
\hline Laminarin & - & $\mathrm{V}$ \\
\hline \multicolumn{3}{|l|}{ Nitrogen source utilization } \\
\hline Asparagine & - & $\mathrm{v}$ \\
\hline Alanine & + & - \\
\hline DNA G $+\mathrm{C}$ content $(\mathrm{mol} \%)$ & 61.9 & $60.5-61.3$ \\
\hline
\end{tabular}


1981) and by using the API 20 NE kit (bioMérieux). Enzyme activities were examined by using the API ZYM kit (bioMérieux). Gelatin liquefaction was assessed according to method 1 of Gerhardt et al. (1981). Cultures were tested for growth under anaerobic conditions in anaerobic jars by using AnaeroGen anaerobic system envelopes (Oxoid) as well as in liquid media recommended for cultivation of phototrophic purple Alphaproteobacteria (Imhoff, 2006). Susceptibility to antibiotics was determined on MB agar plates by using discs (Oxoid) containing the following antibiotics: ampicillin $(10 \mu \mathrm{g})$, gentamicin $(10 \mu \mathrm{g})$, kanamycin $(30 \mu \mathrm{g})$, neomycin $(10 \mu \mathrm{g})$, novobiocin $(30 \mu \mathrm{g})$, streptomycin $(10 \mu \mathrm{g})$, chloramphenicol $(30 \mu \mathrm{g})$ and lincomycin $(10 \mu \mathrm{g})$.

Cell biomass for cellular fatty acid, polar lipid and isoprenoid quinone analyses and for DNA extraction was obtained from batch cultures grown in liquid medium $\mathrm{MB}$ at $24{ }^{\circ} \mathrm{C}$ for 10 days. Fatty acid profiles were analysed at the Identification Service of the Deutsche Sammlung von Mikroorganismen und Zellkulturen (DSMZ, Braunschweig, Germany) as described by Kämpfer \& Kroppenstedt (1996). Isoprenoid quinones were extracted according to Collins (1985) and were analysed by using an LCQ ADVANTAGE MAX tandem-type mass spectrometer and Finnigan Mat 8430 ionization mass spectrometer. Polar lipids were extracted from cell biomass with chloroform/methanol $(1: 2, \mathrm{v} / \mathrm{v})$ by stirring for $1 \mathrm{~h}$ in an ice bath, followed with centrifugation at $5000 \mathrm{~g}$ for $20 \mathrm{~min}$; two phases were separated during this period. The extraction procedure was performed twice and the upper phases were collected and combined. Then, $2 \mathrm{ml}$ chloroform and $2 \mathrm{ml}$ distilled water were added to the supernatant and the resulting mixture was subjected to careful shaking for $15 \mathrm{~min}$ in an ice bath. The mixture was then centrifuged, during which three phases were separated. The lowest phase with polar lipids was withdrawn, evaporated at $30{ }^{\circ} \mathrm{C}$ and dissolved in $200 \mu \mathrm{l}$ chloroform. Polar lipids were separated by two-dimensional TLC (Kieselgel $60,10 \times 10 \mathrm{~cm}$; Merck) by using chloroform/ methanol/7 M sodium hydroxide $(60: 30: 4)$ in the first direction, followed by chloroform/methanol/acetic acid/ water $(85: 12.5: 12.5: 3)$ in the second direction. Plates were sprayed with various specific reagents for detection of different polar lipids (Kates, 1972). Phospholipid standards from Sigma were used during comparative analysis.

The DNA base composition of the novel strains was determined by using thermal denaturation with a Unicam SP1800 spectrophotometer at a heating rate of $0.5{ }^{\circ} \mathrm{C}$ $\min ^{-1}$. The DNA G $+\mathrm{C}$ content was calculated according to Owen et al. (1969). DNA-DNA hybridization experiments were performed as described by De Ley et al. (1970). PCR-mediated amplification of the 16S rRNA gene was performed by using primers $9 \mathrm{f}$ and $1492 \mathrm{r}$ and the reaction conditions described by Weisburg et al. (1991). 16S rRNA gene amplicons were purified by using the Wizard PCR Preps DNA purification system (Promega) and were sequenced on an ABI Prism 377 DNA sequencer (PE
Applied Biosystems). Phylogenetic analysis was carried out by using the ARB program package (Ludwig et al., 2004). The newly obtained $16 \mathrm{~S}$ rRNA gene sequences were added to the ARB database SSU_04 and were aligned manually. Phylogenetic trees were constructed by using distancebased (neighbour-joining), maximum-likelihood (DNAML) and maximum-parsimony methods. Significance levels of interior branch points obtained in the neighbour-joining analysis were determined by bootstrap analysis (1000 data resamplings) by using the PHYLIP program (Felsenstein, 1989).

On agar medium $\mathrm{MB}$, strains $\mathrm{WM}^{\mathrm{T}}$, $\mathrm{TPB} 66^{\mathrm{T}}$ and TPB621 formed circular, convex, slimy colonies with an entire margin and smooth surface. Colony colour varied from white to ivory for strain $\mathrm{WM}^{\mathrm{T}}$ and from white to cream or pinkish for strains $\mathrm{TPB}^{\mathrm{T}} \mathrm{6}^{\mathrm{T}}$ and TPB621. Twoweek-old colonies of these bacteria were $2-5 \mathrm{~mm}$ in diameter. Cells were non-spore-forming, non-motile coccobacilli that stained Gram-negative and occurred singly, in pairs or in chains (see Supplementary Fig. S1, available in IJSEM Online), and were covered with large polysaccharide capsules. Cells multiplied by binary fission and exhibited pleomorphism under variable growth conditions. Cells of tundra strain $\mathrm{WM}^{\mathrm{T}}$ were slightly larger $(0.8-1.5 \times 1.9-4.1 \mu \mathrm{m})$ than those of Siberian strains TPB606 $^{\mathrm{T}}$ and TPB621 $(0.7-1.2 \times 1.4-3.1 \mu \mathrm{m})$ (Table 1$)$. Electron microscopy of ultrathin sections revealed a Gramnegative cell-wall structure and the presence of numerous poly- $\beta$-hydroxybutyrate granules ( 3 or 4 per cell) (Fig. 1 ). Internal photosynthetic membranes were not found. Bacteriochlorophyll $a$ was not detected under any experimental conditions. Low absorption maxima at 480 and $534 \mathrm{~nm}$ were detected in the acetone/methanol extracts of cream-pigmented strains TPB $606^{\mathrm{T}}$ and TPB621, suggesting the presence of a trace amount of the carotenoid spirilloxanthin. No pigments were revealed in cells of strain $\mathrm{WM}^{\mathrm{T}}$. None of the new isolates was capable of anaerobic growth in the light. Stimulation of aerobic growth by continuous incandescent illumination as

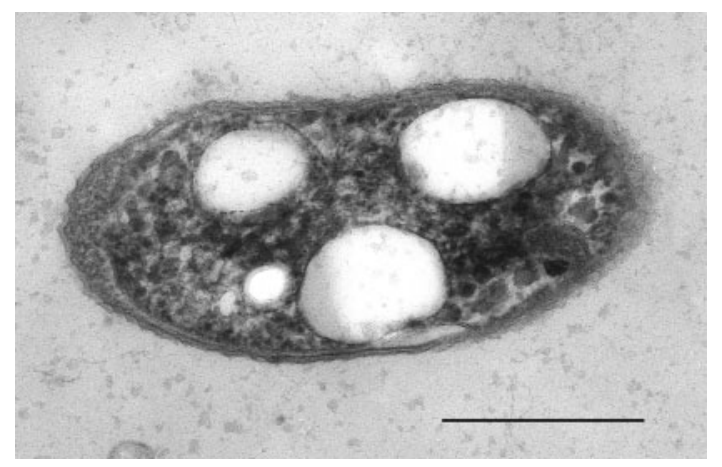

Fig. 1. Electron micrograph of an ultrathin section of a cell of strain $\mathrm{WM}^{\top}$. Large spherical bodies are granules of poly- $\beta$ hydroxybutyrate. Bar, $1 \mu \mathrm{m}$. 
described for Acidisphaera rubrifaciens (Hiraishi et al., 2000) was not detected for the novel strains.

The novel strains from Sphagnum peat were obligately aerobic chemoheterotrophs. They had an absolute requirement for the presence of growth factors $(50-100 \mathrm{mg}$ yeast extract $l^{-1}$ ) in cultivation media. Thus, utilization of a given carbon compound was assumed to have occurred when growth was distinctly improved in its presence compared with in basal MB medium alone. The list of carbon substrates tested and the results are given in the two species descriptions below and are shown in Table 1. Most sugars, polyalcohols and some organic acids were preferable growth substrates. Strain $\mathrm{WM}^{\mathrm{T}}$ differed from strains $\mathrm{TPB} 66^{\mathrm{T}}$ and TPB621 by its ability to utilize ethanol, lactate, malate and butyrate. All the novel strains were able to hydrolyse starch, xylan, heparin and aesculin, whereas pectin was hydrolysed only by tundra strain $\mathrm{WM}^{\mathrm{T}}$. All three strains displayed catalase and cytochrome oxidase activities. Dissimilatory nitrate reduction was negative. Ammonia, nitrate, urea, Bacto yeast extract, glutamine, proline, histidine and methionine were utilized as nitrogen sources. Growth yield on media with nitrate was significantly lower than that on media with ammonia. None of the strains utilized nitrite, $\mathrm{NH}_{2} \mathrm{OH}-\mathrm{HCl}$, lysine, arginine, glycine, serine or $\mathrm{NH}_{4}$-formate as nitrogen sources. All strains were capable of slow growth in liquid nitrogen-free medium MB. The following enzymic activities (API ZYM) were detected in all of the strains: acid phosphatase, esterase, esterase lipase, leucine arylamidase, cystine arylamidase, valine arylamidase and phosphohydrolase. The following enzymic activities were absent: lipase, trypsin, chymotrypsin, $\alpha$-galactosidase, $\beta$-galactosidase, $\beta$ glucuronidase, $\beta$-glucosidase, $N$-acetyl- $\beta$-glucosaminidase, $\alpha$-mannosidase, $\alpha$-fucosidase and arginine dihydrolase. Alkaline phosphatase and urease were detected only in Siberian strains TPB606 ${ }^{\mathrm{T}}$ and TPB621, whereas $\alpha$-glucosidase was detected only in tundra strain $\mathrm{WM}^{\mathrm{T}}$.

Strain $\mathrm{WM} 1^{\mathrm{T}}$ grew in the $\mathrm{pH}$ range 3.0-7.5, with optimum growth at $\mathrm{pH}$ 4.5-5.7 (Supplementary Fig. S2, in IJSEM Online). Strains $\mathrm{TPB}^{2} 6^{\mathrm{T}}$ and TPB621 grew at slightly higher $\mathrm{pH}, 3.7-7.6$, with optimum growth at $\mathrm{pH}$ 5.0-6.5. The temperature range for growth was $2-30{ }^{\circ} \mathrm{C}$, with optimum growth at $15-22{ }^{\circ} \mathrm{C}$ for tundra strain $\mathrm{WM}^{\mathrm{T}}$ and $20-25{ }^{\circ} \mathrm{C}$ for Siberian strains $\mathrm{TPB}^{2} 06^{\mathrm{T}}$ and TPB621. Growth of strain $\mathrm{WM}^{\mathrm{T}}$ was completely inhibited at $\mathrm{NaCl}$ concentrations above $1.5 \%(\mathrm{w} / \mathrm{v})$, but was stimulated at low concentrations $(0.05-0.1 \%, \mathrm{w} / \mathrm{v})$. Strains TPB $606^{\mathrm{T}}$ and TPB621 were able to tolerate higher salinities and were able to grow in media containing up to $2.5 \%(\mathrm{w} / \mathrm{v}) \mathrm{NaCl}$. Under optimal growth conditions, the generation time of these bacteria was in the range 6-10 h. All three strains were susceptible to kanamycin and gentamicin, but resistant to ampicillin and lincomycin. Novobiocin, streptomycin, chloramphenicol and neomycin inhibited growth of strain $\mathrm{WM}^{\mathrm{T}}$ but did not influence growth of strains TPB $606^{\mathrm{T}}$ and TPB621.
Similar to phylogenetically related acidophilic bacteria of the genera Acidisphaera, Acidiphilium, Acidocella and Rhodopila (Hiraishi et al., 2000; Hiraishi \& Imhoff, 2005; Hiraishi, 2005a, b; Madigan \& Imhoff, 2005), the new isolates contained ubiquinone with ten isoprene units (Q10) as the predominant isoprenoid quinone. The major component of the cellular fatty acid profiles of strains $\mathrm{WM}^{\mathrm{T}}, \mathrm{TPB}{ }^{\mathrm{T}} 6^{\mathrm{T}}$ and TPB621 was cyclopropane $\mathrm{C}_{19: 0} \omega 8 \mathrm{c}$, which constituted $44.4-55.4 \%$ of the total fatty acids (Table 2). Interestingly, the presence of this fatty acid has been regarded as a feature specific to Methylocella tundrae, acidophilic, psychrotolerant methanotrophs isolated from acidic wetlands of tundra (Dedysh et al., 2004). Significant amounts of $\mathrm{C}_{18: 1} \omega 7 c(11.1-15.2 \%), \mathrm{C}_{16: 0}$ (4.6-21.3\%) and $\mathrm{C}_{18: 0} 3-\mathrm{OH}(5.6-10.7 \%)$ were also detected in cells of the new isolates. Polar lipid profiles of Siberian strains $\mathrm{TPB}{ }^{\mathrm{T}}{ }^{\mathrm{T}}$ and TPB621 were nearly identical and consisted of phosphatidylcholine, phosphatidylglycerol, diphosphatidylglycerol, phosphatidylethanolamine, an unknown aminolipid, an unknown polar lipid, and minor amounts of phosphatidylserine and several unknown polar lipids (Supplementary Fig. S3a in IJSEM Online; data are shown only for strain $\mathrm{TPB} 606^{\mathrm{T}}$ ). Tundra strain $\mathrm{WM}^{\mathrm{T}}$ contained phosphatidylglycerol, diphosphatidylglycerol, phosphatidylethanolamine, phosphatidylcholine, an

Table 2. Cellular fatty acid compositions (\% of the total) of acidophilic strains $\mathrm{WM}^{\top}{ }^{\top}, \mathrm{TPB} 606^{\top}$ and TPB621

- , Not detected.

\begin{tabular}{|c|c|c|c|}
\hline Fatty acid & $\begin{array}{l}\text { Strain } \\
W M 1^{T}\end{array}$ & $\begin{array}{c}\text { Strain } \\
\text { TPB606 }^{\mathrm{T}}\end{array}$ & $\begin{array}{c}\text { Strain } \\
\text { TPB621 }\end{array}$ \\
\hline $\mathrm{C}_{10: 0}$ & 0.1 & - & - \\
\hline $\mathrm{C}_{12: 0}$ & 0.2 & - & - \\
\hline $\mathrm{C}_{14: 0}$ & 0.2 & 0.7 & 0.5 \\
\hline Unknown 14.959 & 3.1 & 1.4 & 0.7 \\
\hline Summed feature $2^{*}$ & 1.9 & 2.0 & 2.2 \\
\hline Summed feature $3 \dagger$ & - & 1.2 & 0.7 \\
\hline $\mathrm{C}_{16: 0} \mathrm{~N}$ alcohol & 0.4 & - & - \\
\hline$C_{16: 1} \omega 5 c$ & - & 0.2 & - \\
\hline$C_{16: 0}$ & 4.7 & 21.3 & 17.3 \\
\hline Cyclo $\mathrm{C}_{17: 0}$ & - & 1.2 & 0.7 \\
\hline $\mathrm{C}_{16: 0} 2-\mathrm{OH}$ & - & 0.5 & 0.7 \\
\hline $\mathrm{C}_{16: 0} 3-\mathrm{OH}$ & 0.2 & 1.2 & 1.4 \\
\hline $\mathrm{C}_{18: 1} \omega 9 c$ & 2.4 & 0.7 & - \\
\hline $\mathrm{C}_{18: 1} \omega 7 c$ & 11.1 & 13.8 & 15.2 \\
\hline $\mathrm{C}_{18: 1} \omega 5 c$ & 0.4 & - & - \\
\hline $\mathrm{C}_{18: 0}$ & 6.0 & 2.9 & 3.2 \\
\hline 11-Methyl $C_{18: 1} \omega 7 c$ & 1.2 & 0.8 & 0.9 \\
\hline $\mathrm{C}_{17: 0} 3-\mathrm{OH}$ & 0.4 & - & - \\
\hline Cyclo $\mathrm{C}_{19: 0} \omega 8 \mathrm{c}$ & 55.4 & 44.4 & 48.8 \\
\hline $\mathrm{C}_{18: 1} 2-\mathrm{OH}$ & - & 0.8 & 0.6 \\
\hline $\mathrm{C}_{18: 0} 3-\mathrm{OH}$ & 10.7 & 5.6 & 6.1 \\
\hline $\mathrm{C}_{20: 2} \omega 6,9 c$ & 1.4 & 1.1 & 1.0 \\
\hline
\end{tabular}

${ }^{*}$ Summed feature 2 comprises iso- $\mathrm{C}_{16: 1} \mathrm{I}$ and/or $\mathrm{C}_{14: 0} 3-\mathrm{OH}$. $\dagger$ Summed feature 3 comprises $\mathrm{C}_{16: 1} \omega 7 c$ and/or iso- $\mathrm{C}_{15: 0} 2-\mathrm{OH}$. 
unknown aminolipid and an unknown polar lipid as the predominant polar lipids. Additionally, minor amounts of phosphatidylserine, phosphatidic acid and several unknown polar lipids were detected (Supplementary Fig. S3b).

Comparative sequence analysis of the 16S rRNA gene placed strains $\mathrm{WM} 1^{\mathrm{T}}, \mathrm{TPB} 66^{\mathrm{T}}$ and TPB621 in the class Alphaproteobacteria. However, these strains were related only distantly to the type strains of acidophilic alphaproteobacteria Acidisphaera rubrifaciens (93.4-94.3\% $16 \mathrm{~S}$ rRNA gene sequence similarity), Rhodopila globiformis $(92.2-93.3 \%)$, and members of the genera Acidiphilium (91.3-93\%) and Acidocella (91.8-92.4\%) (Fig. 2). The two strains isolated from Siberian wetland, $\mathrm{TPB}^{\mathrm{T}} \mathrm{6}^{\mathrm{T}}$ and TPB621, possessed almost identical 16S rRNA gene sequences and shared $97.2 \%$ sequence similarity with tundra strain $\mathrm{WM1}^{\mathrm{T}}$. The DNA G+C content of strains $\mathrm{WM}_{1}^{\mathrm{T}}, \mathrm{TPB}^{\mathrm{T}} 6^{\mathrm{T}}$ and $\mathrm{TPB} 621$ was $61.9,60.5$ and $61.3 \mathrm{~mol} \%$, respectively. Levels of DNA-DNA relatedness between strains $\mathrm{WM}^{\mathrm{T}}$ and $\mathrm{TPB} 606^{\mathrm{T}}$ and between strains $\mathrm{TPB}^{2} 6^{\mathrm{T}}$ and TPB621 were 37 and $79 \%$, respectively. Thus, the results of DNA-DNA hybridization experiments indicated that the two Siberian strains and the strain isolated from tundra represent two separate species. This conclusion was also supported by significant morphological and phenotypic differences between these strains (Table 1) as well as by clear differences in their cellular fatty acid compositions (Table 2) and polar lipid profiles (Supplementary Fig. S3). Compared with data for the isolate from tundra, cells of the two Siberian strains were smaller, contained carotenoids, were less acidophilic and psychrotolerant, and were more resistant to $\mathrm{NaCl}$.

In summary, the novel isolates from Sphagnum-dominated wetlands possessed a number of characteristics that clearly distinguished them from phylogenetically related members of the Alphaproteobacteria (Table 3). They could be differentiated from members of the genera Acidisphaera, Acidiphilium, Rhodopila, Craurococcus, Paracraurococcus, Roseococcus and Roseomonas based on the absence of bacteriochlorophyll $a$. Absence of motility distinguished them from members of the genera Acidocella, Acidiphilium, Rhodopila and Roseococcus. They could be differentiated from members of the genus Acidocella based on the presence of diphosphatidylglycerol in polar lipid profiles. Compared with the phylogenetically related bacteria listed in Table 3, strains $\mathrm{WM1}^{\mathrm{T}}$, $\mathrm{TPB} 06^{\mathrm{T}}$ and TPB621 had greater tolerance to low temperatures, were more sensitive to $\mathrm{NaCl}$ and possessed distinct fatty acid profiles. Thus, strain $\mathrm{WM1}^{\mathrm{T}}$ and strains $\mathrm{TPB}^{\mathrm{T}} \mathrm{6}^{\mathrm{T}}$ and TPB621 are considered to represent two novel species of a new genus, for which the names Acidisoma tundrae gen. nov., sp. nov. and Acidisoma sibiricum sp. nov. are proposed.

\section{Description of Acidisoma gen. nov.}

Acidisoma [A.ci.di.so'ma. M.L. n. acidum in acid; Gr. neut. n. soma body; M.L. neut. n. Acidisoma an acid (-requiring) body].

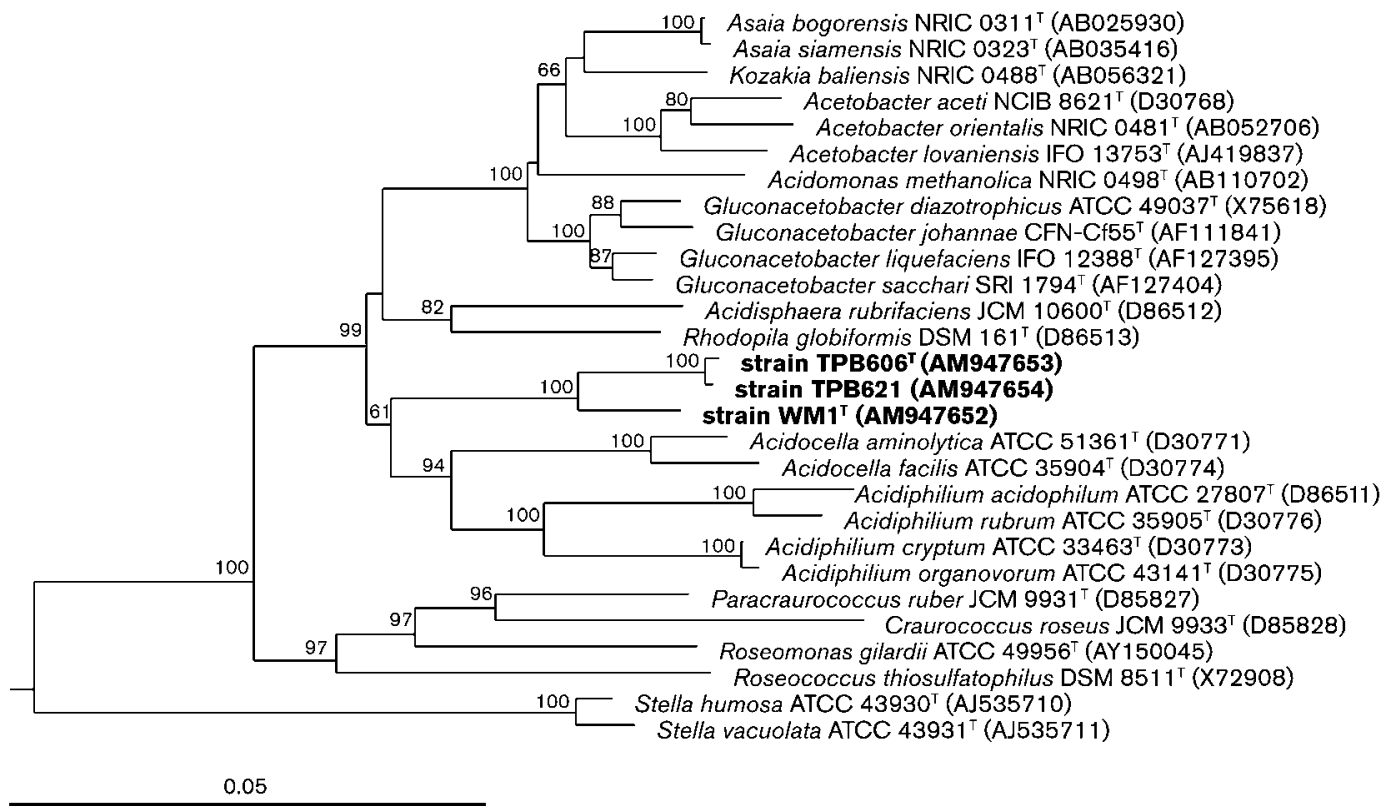

Fig. 2. Neighbour-joining tree based on $16 \mathrm{~S}$ rRNA gene sequences showing the phylogenetic position of strains $\mathrm{WM} 1^{\top}$, TPB $606^{\top}$ and TPB621 in relation to some representatives of the family Acetobacteraceae. The tree was constructed based on 1280 nt positions. Bootstrap values (based on 1000 data resamplings) of $>50 \%$ are shown at nodes. The 16S rRNA gene sequence of Rhodospirillum rubrum (GenBank no. D30778) was used as an outgroup (not shown). Bar, 0.05 substitutions per nucleotide position. The same tree topology was obtained with the maximum-likelihood and maximum-parsimony methods. 
Table 3. Major characteristics that distinguish Acidisoma gen. nov. from phylogenetically related genera of the Alphaproteobacteria

Genera: 1, Acidisoma gen. nov.; 2, Acidisphaera (data from Hiraishi et al., 2000; Hiraishi, 2005a); 3, Rhodopila (Madigan \& Imhoff, 2005); 4, Acidiphilium (Hiraishi \& Imhoff, 2005); 5, Acidocella (Hiraishi, 2005b); 6, Craurococcus (Saitoh et al., 1998); 7, Paracraurococcus (Saitoh et al., 1998); 8, Roseococcus (Yurkov, 2005); 9, Roseomonas (Weyant \& Whitney, 2005); 10, Stella (Vasilyeva, 2005). NA, Data not available; v, variable; w, weakly positive.

\begin{tabular}{|c|c|c|c|c|c|c|c|c|c|c|}
\hline Characteristic & 1 & 2 & 3 & 4 & 5 & 6 & 7 & 8 & 9 & 10 \\
\hline Cell shape & Coccobacilli & Cocci, short rods & Cocci & Rods & Rods, coccobacilli & Cocci & Cocci & Cocci & $\begin{array}{l}\text { Cocci, cocco- } \\
\text { bacilli }\end{array}$ & Flat stars \\
\hline Cell size $(\mu \mathrm{m})$ & $0.7-1.5 \times 1.4-4.1$ & $0.7-0.9 \times 0.9-1.6$ & $1.6-1.8$ & $0.3-1.2 \times 4.2$ & $0.5-0.8 \times 1.0-2.0$ & $0.8-2.0$ & $0.8-1.5$ & $0.9-1.6$ & $\mathrm{NA}$ & $0.7-3.0$ \\
\hline Motility & - & - & + & + & + & - & - & + & $\mathrm{V}$ & - \\
\hline Colony colour & White, cream & Salmon-pink & Purple-red & Pink, red & $\begin{array}{c}\text { White, cream, light } \\
\text { brown }\end{array}$ & Pink & Red & Pink & Pale pink & $\begin{array}{c}\text { Greyish } \\
\text { white }\end{array}$ \\
\hline Bacteriochlorophyll $a$ & - & + & + & + & - & + & + & + & + & - \\
\hline Anaerobic phototrophy & - & - & + & - & - & - & - & - & $\mathrm{NA}$ & - \\
\hline Optimal growth temperature $\left({ }^{\circ} \mathrm{C}\right)$ & $18-22$ & $30-35$ & $30-35$ & $27-30$ & $31-41$ & $28-32$ & $30-34$ & $25-30$ & 35 & $28-30$ \\
\hline Growth below $5{ }^{\circ} \mathrm{C}$ & + & - & - & - & - & - & - & - & - & NA \\
\hline $\mathrm{pH}$ range & $3.7-7.5$ & $3.5-6.0$ & $4.2-6.5$ & $2.0-5.9$ & $3.0-6.0$ & $>6.8$ & NA & $6-9$ & NA & NA \\
\hline Optimal growth $\mathrm{pH}$ & $5.0-5.7$ & $4.5-5.0$ & $4.8-5.0$ & $3.2-3.5$ & NA & 7.5 & $6.6-6.8$ & $7-8$ & NA & $7-8$ \\
\hline Growth at pH 7 & + & - & - & - & - & + & + & + & NA & + \\
\hline Tolerance of $>2.5 \% \mathrm{NaCl}$ & - & + & + & + & + & + & + & NA & + & - \\
\hline Major quinone(s) & Q-10 & Q-10 & $\begin{array}{c}\text { Q-9 (10), MK- } \\
9(10), \text { RQ-9 } \\
(10)\end{array}$ & Q-10 & Q-10 & Q-10 & Q-10 & NA & NA & NA \\
\hline Major fatty acid & Cyclo $\mathrm{C}_{19: 0} \omega 8 \mathrm{c}$ & NA & $\mathrm{C}_{18: 1}$ & $\mathrm{C}_{18: 1}$ & $\mathrm{C}_{18: 1}$ & $\mathrm{C}_{18: 1}$ & $\mathrm{C}_{18: 1}$ & NA & $\mathrm{C}_{18: 1}$ & NA \\
\hline Diphosphatidylglycerol & + & NA & NA & + & - & NA & NA & NA & NA & NA \\
\hline Oxidase & + & + & NA & $-/ \mathrm{w}$ & $-/ \mathrm{w}$ & + & + & + & $\mathrm{V}$ & + \\
\hline DNA G $+\mathrm{C}$ content $(\mathrm{mol} \%)$ & $60.5-61.9$ & $69.1-69.8$ & 66.3 & $62.9-68.3$ & $58.7-64.4$ & 70.5 & $70.3-71.0$ & 70.4 & $65-71$ & $69.3-73.5$ \\
\hline
\end{tabular}


Non-spore-forming, non-motile coccobacilli that occur singly, in pairs or in chains and are covered by large capsules. Cells stain Gram-negative and have a Gramnegative cell-wall structure as revealed by electron microscopy. Colonies are circular, smooth, convex and slimy. Colony colour varies from white to cream and pinkish. Bacteriochlorophyll $a$ is absent. Produce poly- $\beta$-hydroxybutyrate. Oxidase- and catalase-positive. Chemo-organotrophic strict aerobes. Sugars, polyalcohols and some organic acids are the preferred growth substrates. Hydrolyse starch, heparin, xylan and aesculin. Some strains can utilize laminarin, pectin and fucoidan. Dissimilatory nitrate reduction is negative. Moderately acidophilic and psychrotolerant. The major cellular fatty acid is cyclo $\mathrm{C}_{19: 0} \omega 8 c$, the major quinone is $\mathrm{Q}-10$. Phosphatidylcholine, diphosphatidylglycerol, phosphatidylethanolamine, phosphatidylglycerol and an unknown aminolipid are present as major phospholipids. The $\mathrm{G}+\mathrm{C}$ content of the DNA varies between 60.5 and $61.9 \mathrm{~mol} \%$. Member of the class Alphaproteobacteria. The type species is Acidisoma tundrae.

\section{Description of Acidisoma tundrae sp. nov.}

Acidisoma tundrae (tun'drae. N.L. gen. fem. n. tundrae from the tundra, of the northern zone of Eurasia and North America).

The description is as for the genus but with the following additional traits. Cells are $0.8-1.5 \mu \mathrm{m}$ wide and $1.9-4.1 \mu \mathrm{m}$ long. Colony colour is white or ivory. Able to utilize the following carbon sources $(0.05 \%, \mathrm{w} / \mathrm{v})$ : sorbose, myoinositol, gluconate, lactate, pyruvate, galacturonic acid, yeast extract, Casamino acids, peptone, asparagine, butyrate, glycerol, arabinose, mannose, glucose, trehalose, dulcitol, ethanol, sorbitol, xylose, fructose, malate, galactose and mannitol. Unable to utilize acetate, propionate, capronate, formate, citrate, benzoate, succinate, methanol, butanol, glucuronic acid, alanine, leucine, maltose, raffinose, fumarate, lactose, oxalate, cellobiose, sucrose or aspartate. Capable of hydrolysing fucoidan and pectin, but not laminarin, pullulan, alginate, carboxymethylcellulose or chondroitin sulfate. The following enzyme activities are present: acid phosphatase, esterase, esterase lipase, leucine arylamidase, cystine arylamidase, valine arylamidase, phosphohydrolase and $\alpha$-glucosidase (API ZYM test). Able to utilize the following nitrogen sources $(0.05 \%$, w $/ \mathrm{v})$ : ammonia, urea, Bacto yeast extract, histidine $\mathrm{HCl}$, proline, alanine, methionine, glutamine and nitrate. Contains phosphatidylcholine, phosphatidylglycerol, diphosphatidylglycerol, phosphatidylethanolamine and an unknown aminolipid as predominant polar lipids. Phosphatidylserine, phosphatidic acid and several unknown polar lipids are present in minor amounts. Resistant to ampicillin and lincomycin, but susceptible to kanamycin, novobiocin, gentamicin, streptomycin, chloramphenicol and neomycin. Capable of growth at $\mathrm{pH}$ 3.0-7.5 (optimum, $\mathrm{pH} 4.5-5.7$ ) and at $2-30{ }^{\circ} \mathrm{C}$ (optimum, $15-22{ }^{\circ} \mathrm{C}$ ). $\mathrm{NaCl}$ inhibits growth at concentrations above $1.5 \%(\mathrm{w} / \mathrm{v})$.
The type strain, $\mathrm{WM}^{\mathrm{T}}\left(=\mathrm{DSM} 19999^{\mathrm{T}}=\mathrm{VKM} \mathrm{B}-2488^{\mathrm{T}}\right)$, was isolated from an acidic oligotrophic Sphagnumdominated wetland in the Vorkuta region of northern Russia.

\section{Description of Acidisoma sibiricum sp. nov.}

Acidisoma sibiricum (si.bi' ri.cum. N.L. neut. adj. sibiricum from Siberia, the region of Russia from where the type strain was isolated).

The description is as for the genus but with the following additional traits. Cells are $0.7-1.2 \mu \mathrm{m}$ wide and 1.4$3.1 \mu \mathrm{m}$ long. Spirilloxanthin is present in small amounts. Able to utilize the following carbon sources $(0.05 \%$, w/v): sorbitol, arabinose, galactose, fructose, sorbose, myoinositol, mannitol, dulcitol, glycerol, gluconate, pyruvate, galacturonic acid, yeast extract, Casamino acids, peptone, asparagine, xylose and glucose. Utilization of lactose, trehalose, mannose, cellobiose and sucrose is variable. Cannot utilize acetate, propionate, butyrate, capronate, formate, oxalate, citrate, benzoate, succinate, lactate, malate, ethanol, propanol, butanol, glucuronic acid, raffinose, maltose, fumarate, alanine, aspartate or leucine. Does not hydrolyse pullulan, pectin, alginate, carboxymethylcellulose or chondroitin sulfate. The ability to hydrolyse laminarin and fucoidan is variable. The following enzyme activities are present: alkaline phosphatase, acid phosphatase, esterase, esterase lipase, leucine arylamidase, cystine arylamidase, valine arylamidase, phosphohydrolase and urease (API ZYM test). Able to utilize the following nitrogen sources $(0.05 \%$, w/v): ammonia, urea, Bacto yeast extract, glutamine, proline, histidine $\mathrm{HCl}$, methionine and nitrate. Utilization of asparagine is variable. Contains phosphatidylcholine, phosphatidylethanolamine, phosphatidylglycerol, diphosphatidylglycerol, an unknown aminolipid and an unknown polar lipid as major lipids. Phosphatidylserine and several unknown polar lipids are present in minor amounts. Resistant to ampicillin, lincomycin, novobiocin, streptomycin, chloramphenicol and neomycin, but susceptible to kanamycin and gentamicin. Capable of growth at $\mathrm{pH} 3.7-7.6$ (optimum, $\mathrm{pH} 5.0-6.5$ ) and at $2-30{ }^{\circ} \mathrm{C}$ (optimum, $20-25^{\circ} \mathrm{C}$ ). $\mathrm{NaCl}$ inhibits growth at concentrations above $2.5 \%(\mathrm{w} / \mathrm{v})$.

The type strain, TPB $606^{\mathrm{T}}\left(=\mathrm{DSM} \quad 21000^{\mathrm{T}}=\mathrm{VKM} \quad \mathrm{B}-\right.$ $2487^{\mathrm{T}}$ ), was isolated from the Sphagnum peat bog Bakchar in the Tomsk region of western Siberia. TPB621, isolated from the same locality, is a second strain of the species.

\section{Acknowledgements}

This research was supported by the program 'Molecular and Cell Biology' of the Russian Academy of Sciences, the Russian Science Support Foundation and the Russian Fund of Basic Research (grant no. 07-04-91561). We thank N. E. Suzina for electron microscopy. 


\section{References}

Collins, M. D. (1985). Analysis of isoprenoid quinones. Methods Microbiol 18, 329-366.

Dedysh, S. N., Berestovskaya, Y. Y., Vasylieva, L. V., Belova, S. E., Khmelenina, V. N., Suzina, N. E., Trotsenko, Y. A., Liesack, W. \& Zavarzin, G. A. (2004). Methylocella tundrae sp. nov., a novel methanotrophic bacterium from acidic tundra peatlands. Int J Syst Evol Microbiol 54, 151-156.

Dedysh, S. N., Pankratov, T. A., Belova, S. E., Kulichevskaya, I. S. \& Liesack, W. (2006). Phylogenetic analysis and in situ identification of bacteria community composition in an acidic Sphagnum peat bog. Appl Environ Microbiol 72, 2110-2117.

De Ley, J., Cattoir, K. \& Reynaerts, A. (1970). The quantitative measurement of DNA hybridization from renaturation rates. Eur $J$ Biochem 12, 133-142.

Felsenstein, J. (1989). PHYLIP - phylogeny inference package (version 3.2). Cladistics 5, 164-166.

García-Moyano, A., Gonzáles-Toril, E., Aguilera, A. \& Amils, R. (2007). Prokaryotic community composition and ecology of floating macroscopic filaments from an extreme acidic environment, Río Tinto (SW, Spain). Syst Appl Microbiol 30, 601-614.

Gerhardt, P., Murray, R. G. E., Costilow, R. N., Nester, E. W., Wood, W. A., Krieg, N. R. \& Phillips, G. B. (editors) (1981). Manual of Methods for General Bacteriology. Washington, DC: American Society for Microbiology.

Harrison, A. P., Jr (1981). Acidiphilium cryptum gen. nov., sp. nov., heterotrophic bacterium from acidic mineral environments. Int J Syst Bacteriol 31, 327-332.

Hiraishi, A. (2005a). Genus III. Acidisphaera. In Bergey's Manual of Systematic Bacteriology, pp. 62-64. Edited by G. M. Garrity. New York: Springer.

Hiraishi, A. (2005b). Genus IV. Acidocella. In Bergey's Manual of Systematic Bacteriology, pp. 65-68. Edited by G. M. Garrity. New York: Springer.

Hiraishi, A. \& Imhoff, J. F. (2005). Genus II. Acidiphilium. In Bergey's Manual of Systematic Bacteriology, pp. 54-62. Edited by G. M. Garrity. New York: Springer.

Hiraishi, A., Nagashima, K. V. P., Matsuura, K., Shimada, K., Takaichi, S., Wakao, N. \& Katayama, Y. (1998). Phylogeny and photosynthetic features of Thiobacillus acidophilus and related acidophilic bacteria: its transfer to the genus Acidiphilium as Acidiphilium acidophilum comb. nov. Int J Syst Bacteriol 48, 13891398.

Hiraishi, A., Matsuzawa, Y., Kanbe, T. \& Wakao, N. (2000). Acidisphaera rubrifaciens gen. nov., sp. nov., an aerobic bacteriochlorophyll-containing bacterium isolated from acidic environments. Int J Syst Evol Microbiol 50, 1539-1546.
Imhoff, J. F. (2006). The phototrophic Alpha-Proteobacteria. In The Prokaryotes, 3rd edn, vol. 5, pp. 41-64. Edited by M. Dworkin, S. Falkow, E. Rosenberg, K.-H. Schleifer \& E. Stackebrandt. New York: Springer.

Kämpfer, P. \& Kroppenstedt, R. M. (1996). Numerical analysis of fatty acid patterns of the coryneform bacteria and related taxa. Can $J$ Microbiol 42, 989-1005.

Kates, M. (1972). Techniques of Lipidology. New York: American Elsevier Publishing Co., Inc.

Kishimoto, N., Kosako, Y., Wakao, N., Tano, T. \& Hiraishi, A. (1995). Transfer of Acidiphilium facilis and Acidiphilium aminolytica to the genus Acidocella gen. nov., and emendation of the genus Acidiphilium. Syst Appl Microbiol 18, 85-91.

Kulichevskaya, I. S., Guzev, V. S., Gorlenko, V. M., Liesack, W. \& Dedysh, S. N. (2006). Rhodoblastus sphagnicola sp. nov., a novel acidophilic purple non-sulfur bacterium from Sphagnum peat bog. Int J Syst Evol Microbiol 56, 1397-1402.

Ludwig, W., Strunk, O., Westram, R., Richter, L., Meier, H., Yadhukumar, Buchner, A., Lai, T., Steppi, S., Jobb, G. \& other authors (2004). ARB: a software environment for sequence data. Nucleic Acids Res 32, 1363-1371.

Madigan, M. T. \& Imhoff, J. F. (2005). Genus XI. Rhodopila. In Bergey's Manual of Systematic Bacteriology, pp. 83-85. Edited by G. M. Garrity. New York: Springer.

Nogales, B., Moore, E. R. B., Llobet-Brossa, E., Rossello-Mora, R., Amann, R. \& Timmis, K. N. (2001). Combined use of $16 \mathrm{~S}$ ribosomal DNA and 16S rRNA to study the bacterial community of polychlorinated biphenyl-polluted soil. Appl Environ Microbiol 67, 1874-1884.

Owen, R. J., Lapage, S. P. \& Hill, L. R. (1969). Determination of base composition from melting profiles in dilute buffers. Biopolymers 7 , 503-516.

Saitoh, S., Suzuki, T. \& Nishimura, Y. (1998). Proposal of Craurococcus roseus gen. nov., sp. nov. and Paracraurococcus ruber gen. nov., sp. nov., novel aerobic bacteriochlorophyll $a$-containing bacteria from soil. Int J Syst Bacteriol 48, 1043-1047.

Vasilyeva, L. V. (2005). Genus XIV. Stella. In Bergey's Manual of Systematic Bacteriology, pp. 93-95. Edited by G. M. Garrity. New York: Springer.

Weisburg, W. G., Barns, S. M., Pelletier, D. A. \& Lane, D. J. (1991). $16 \mathrm{~S}$ ribosomal DNA amplification for phylogenetic study. J Bacteriol 173, 697-703.

Weyant, R. S. \& Whitney, A. M. (2005). Genus XIII. Roseomonas. In Bergey's Manual of Systematic Bacteriology, pp. 88-93. Edited by G. M. Garrity. New York: Springer.

Yurkov, V. V. (2005). Genus XII. Roseococcus. In Bergey's Manual of Systematic Bacteriology, pp. 85-87. Edited by G. M. Garrity. New York: Springer. 